\title{
KARAKTERISTIK BATUBARA TERPENGARUH INTRUSI DI TAMBANG AIR LAYA, SUMATRA SELATAN DAN POTENSINYA SEBAGAI MATERIAL UNTUK PEMBUATAN GRAFIT SINTETIS
}

\section{THE CHARACTERISTICS OF HEAT-AFFECTED COAL IN AIR LAYA MINE, SOUTH SUMATRA AND ITS POTENTIAL AS AN ALTERNATIVE SOURCE OF SYNTHETIC GRAPHITE}

\author{
Arsha Maulana ${ }^{1}$ dan Ferian Anggaraa ${ }^{2,3}$ \\ ${ }^{1}$ Program Studi S1, Departemen Teknik Geologi, Fakultas Teknik, UGM \\ ${ }^{2}$ Departemen Teknik Geologi, Fakultas Teknik, UGM \\ ${ }^{3}$ Pusat Kajian Sumberdaya Bumi Non-konvensional, Fakultas Teknik, UGM \\ ferian@ugm.ac.id
}

\begin{abstract}
ABSTRAK
Grafit dapat diaplikasikan dalam berbagai macam kegunaan misal sebagai material tahan panas, baterai, dan elektroda. Material grafit bisa didapat melalui grafit sintetis yang berasal dari batubara antrasit yang terpanaskan pada suhu di atas $2000^{\circ} \mathrm{C}$. Kondisi batubara yang terpanaskan secara alami dapat ditemui pada batubara yang terpengaruh intrusi batuan beku di Tambang Air Laya (TAL), Tanjung Enim, Sumatra Selatan. Penelitian ini bertujuan untuk mengetahui karakteristik batubara terpengaruh intrusi batuan beku dan potensinya sebagai material untuk pembentukan grafit sintetis. Empat sampel batubara yang berasal dari 4 seam dengan jarak bervariasi terhadap intrusi diambil dan dipreparasi untuk dilakukan analisis sayatan poles, random vitrinite reflectance $\left(R_{v r}\right)$, proksimat, $X$-Ray Diffractometry $(\mathrm{XRD})$, Total Carbon (TC), Total Organic Carbon (TOC), Total Inorganic Carbon (TIC), serta analisis microRaman spectroscopy. Batubara terpengaruh intrusi batuan beku di lokasi penelitian mengalami kenaikan vitrinite reflectance dan kandungan fixed carbon (karbon tertambat) serta penurunan nilai moisture (kadar lengas) dan volatile matter (zat terbang) seiring berkurangnya jarak terhadap tubuh intrusi. Batubara seam A1 berperingkat low volatile bituminous coal $(\% \mathrm{Ro}=2,01 \%)$ yang memiliki jarak terdekat dengan tubuh intrusi memiliki derajat pembatubaraan dan kandungan presentase mineral tertinggi. Batubara seam A1 memiliki banyak asosiasi mineral lempung yang dijumpai seperti ilit, smektit, dan rektorit sehingga dapat meningkatkan derajat kristalinitas dalam proses pembatubaraan dan akan mempermudah pada proses pembentukan grafit sintesis dalam proses selanjutnya.
\end{abstract}

Kata kunci: Batubara, Intrusi, Tambang Air Laya, Karakteristik Batubara, Grafit

\section{ABSTRACT}

Graphite can be applied in various uses for example as a heat resistant materials, batteries, and electrodes. Graphite material can be obtained from synthetic graphite which produced from anthracite coal that is heated at $2000^{\circ} \mathrm{C}$ or above. Naturally heat affected coal can be found in Tambang Air Laya (TAL), Tanjung Enim, South Sumatra where the coal is affected by the presence of igneous intrusion. According to these conditions, it is important to conduct the research to determine the characteristics of heat affected coal and its potential as an alternative source of synthetic graphite. Four samples of heat affected coal obtained from four seams with varying distances to the body of igneous intrusion are prepared for several analyses, namely petrographic, random vitrinite reflectance $\left(R_{v r}\right)$, proximate, X-Ray Diffractometry (XRD), Total Carbon (TC), Total Organic Carbon (TOC), and Total Inorganic Carbon (TIC), as well as micro-Raman spectroscopy. The heat affected coal shows the tendency of increasing vitrinite reflectance and fixed carbon content and decreasing moisture and volatile matter towards the igneous intrusion body. The heat affected coal (A1 Coal) with 


\section{MAKALAH ILMIAH}

the closest distance to the igneous intrusion body has the highest rank (low volatile bituminous coal; $\% R o=2,01 \%$ ) and mineral percentage. A1 Coal is associated with mineral lempung such as illite, smectite, and rektorit that can increase the degree of crystalinity in the process of coalification and that would catalyze the formation of synthetic graphite in the next process.

Keywords: Coal, Intrusion, Tambang Air Laya, Coal Characteristics, Graphite

\section{PENDAHULUAN}

Pemanfaatan grafit global sejak 2013 meningkat terus tiap tahunnya (Simandl et al., 2015). Hal ini disebabkan oleh meningkatnya kondisi ekonomi global serta dampaknya terhadap industri yang menggunakan grafit (Olson, 2015). Grafit merupakan material yang dapat diaplikasikan dalam berbagai macam kegunaan misal sebagai material tahan panas, baterai, dan elektroda.

Grafit terbentuk sebagai hasil dari tahapan metamorfisme kontak maupun regional dari sedimen yang kaya akan material organik. Grafit memiliki banyak kegunaaan terutama pada bidang industri (Chung, 2002). Untuk mencukupi kebutuhan grafit dunia, petroleum coke merupakan material karbon yang biasa digunakan sebagai grafit sintetis. Berdasarkan penelitian Franklin (1951) dan Oberlin \& Terriere (1975) diketahui bahwa antrasit dapat tergrafitisasi dengan mudah apabila terpanaskan pada temperatur di atas 2000 ${ }^{\circ} \mathrm{C}$. Oleh karena itu, batubara dapat digunakan sebagai bahan baku pembuatan grafit sintetis.

Batubara yang terpanaskan secara alami akibat pengaruh intrusi batuan beku sehingga peringkatnya naik dapat di jumpai di lapangan Tambang Air Laya (TAL), Sumatra Selatan (Gambar 1). Batubara di lokasi penelitian termasuk dalam Formasi Muara Enim (Gambar 2). Temperatur kontak intrusi batuan beku yang hadir di lapangan TAL berkisar antara $700-750^{\circ} \mathrm{C}$ (Amijaya dan Littke, 2005). Intrusi ini memberikan panas dengan temperatur tinggi sehingga dapat mempengaruhi karakteristik awal dari batubara (Pujobroto,
1997). Berdasarkan Levine (1993) dikatakan bahwa intrusi batuan beku yang hadir dapat memberikan efek panas yang diberikan sehingga menyebabkan adanya peningkatkan derajat pembatubaraan atau peningkatkan peringkat batubara di lokasi tertentu baik secara lokal ataupun secara regional yang salah satu contohnya terjadi pada batubara Cekungan Narragganset, Rhode Island (Lyons and Chase, 1981).

Berdasarkan hal tersebut, penelitian ini dilakukan untuk mengetahui karakteristik batubara terpengaruh intrusi batuan beku di TAL dan potensinya sebagai material untuk pembuatan grafit sintesis.

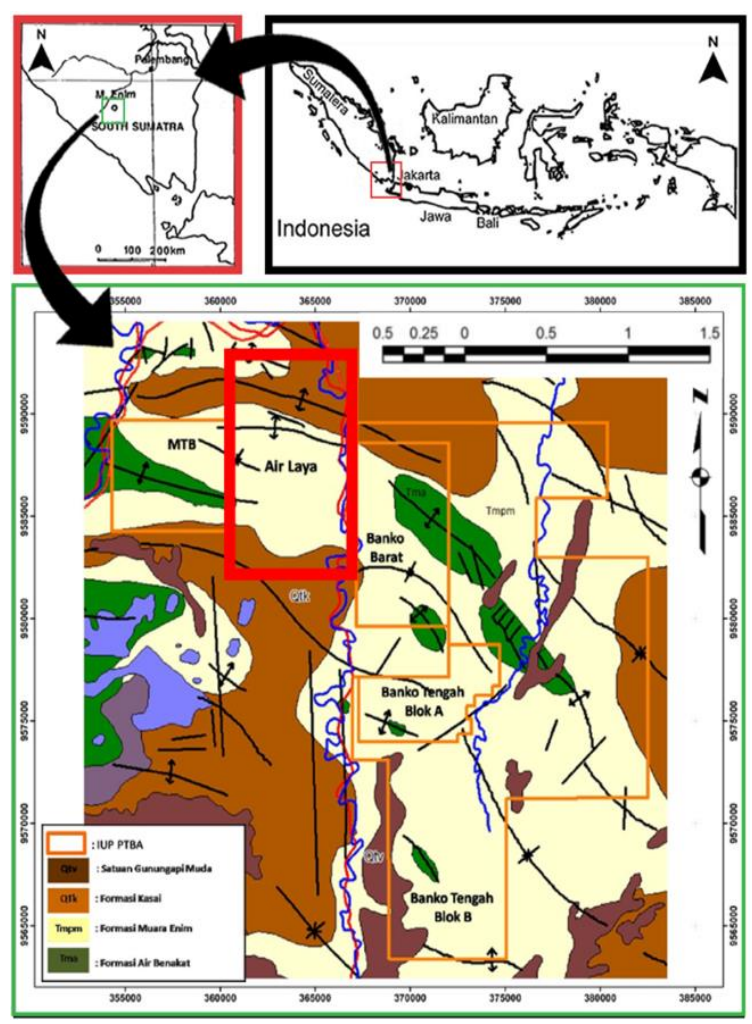

Gambar 1. Peta indeks lokasi penelitian, Lokasi penelitian berada pada Tambang Air Laya (dimodifikasi dari Pujobroto, 1997) 


\section{MAKALAH ILMIAH}

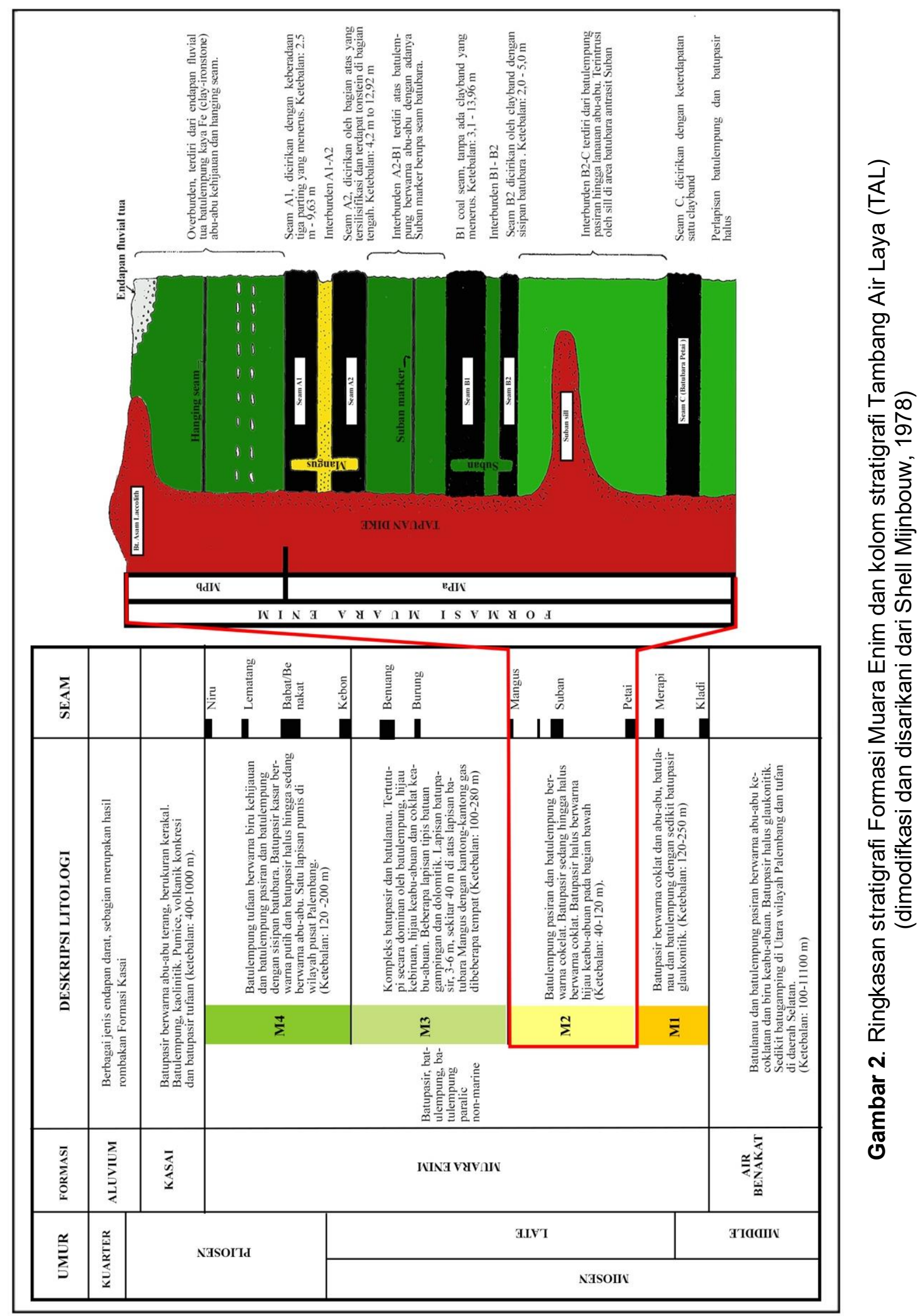




\section{GEOLOGI}

Daerah penelitian berada di Cekungan Sumatra Selatan yang merupakan cekungan busur belakang yang terbentuk akibat ekstensi timur-barat pada Pre-Tersier hingga Tersier Awal (de Coster, 1974; Daly et al., 1987).

Berdasarkan Pujobroto and Hutton (2000) terdapat tiga tubuh intrusi utama yang bersifat andesitik yang berada di sekitar TAL. Tiga intrusi tersebut adalah: 1) Intrusi dike Bukit Asam; 2) Intrusi sill Suban; dan 3) kerucut vulkanik atau vertical parasitic cone. Intrusi tersebut hadir ketika Plio-Pleistosen (Darman dan Sidi, 2000).

Batubara pada TAL merupakan bagian dari Formasi Muara Enim yang terendapkan ketika Miosen Akhir - Pliosen Awal (de Coster, 1974). Terdapat tiga lapisan batubara yang dinilai ekonomis yang tersusun oleh batubara berlitotipe banded bright: Mangus (A1, A2) seam, Suban (B1, B2) seam, dan Petai (C) seam (Shell Mijnbouw, 1978). Secara umum, batubara di TAL dapat dibagi menjadi dua yakni, 1) Batubara normal; dan 2) Batubara terpengaruh intrusi batuan beku. Batubara normal $\left(\mathrm{VR}_{\max }\right.$ sekitar $\left.\quad 0,40 \%-0,50 \%\right)$ adalah batubara yang mengalami tahapan pembatubaraan dengan tahapan burial atau pembebanan yang normal sedangkan batubara terpengaruh intrusi $\left(\mathrm{VR}_{\max } 0,60 \%\right.$ - 2,70\%) merupakan batubara yang mengalami pembatubaraan secara cepat akibat hadirnya panas dari intrusi batuan beku secara tiba-tiba sehingga mengalami perubahan karakteristik seperti kenaikkan derajat pembatubaraan atau peringkat dari batubara tersebut (Daulay et al, 2000; Pujobroto and Hutton, 2000).

\section{METODOLOGI}

Pengambilan sampel batubara dengan metode bulk sampling dilakukan di Tambang
Air Laya (TAL) pada seam batubara A1 (1 sampel), A2 (1 sampel), B1 (1 sampel), dan B2 (1 sampel) dengan interval jarak pengambilan terhadap tubuh intrusi dike yang sudah ditentukan. Sampel A1 memiliki jarak terdekat $( \pm 0-5 \mathrm{~m})$ terhadap kontak tubuh intrusi dike dan secara berurutan hingga sampel batubara B2 yang memiliki jarak terjauh $( \pm 25 \mathrm{~m})$. Dilakukan pula akuisisi data log yang didapat dari sumur bor BGT_19 PT Bukit Asam (Persero), Tbk yang terletak $100 \mathrm{~m}$ di Timur dari titik pengambilan sampel (Gambar 3). Deskripsi makroskopis tiap sampel di lapangan digunakan sebagai data acuan awal untuk melihat perubahan karakteristik fisik dari batubara yang dipengaruhi intrusi.

Tiap sampel yang diperoleh dipreparasi untuk sayatan poles serta analisis proksimat. Analisis petrografi batubara mengacu pada ASTM-D2799-05a (2005) dan identifikasi maseral dilakukan berdasarkan ICCP System 1994 (1998) untuk vitrinit, ICCP (2001) untuk inertinit, dan Pickel et al., (2017) untuk liptinit. Analisis proksimat dilakukan sesuai dengan ASTM Standards D3172-13 (2013) untuk memperoleh nilai ash yield (kadar abu), moisture (kadar lengas), volatile matter (kadar zat terbang), dan fixed carbon (karbon tertambat). Analisis random vitrinite reflectance $\left(R_{v r}\right)$ atau reflektansi vitrinite dilakukan dengan mengikuti rekomendasi dari ISO 7404-5 (2009) dan analisis microRaman Spectroscopy dilakukan untuk mengetahui derajat pembatubaraan atau peringkat batubara. Analisis $X$-ray diffraction (XRD) untuk mengidentifikasi mineralogi yang hadir dengan mengacu pada Chen (1997). Analisis total carbon (TC), total inorganic carbon (TIC), dan total organic carbon (TOC) menggunakan Elementar Soli TOC® cube (Girard, 2001) juga dilakukan untuk seluruh sampel penelitian. 


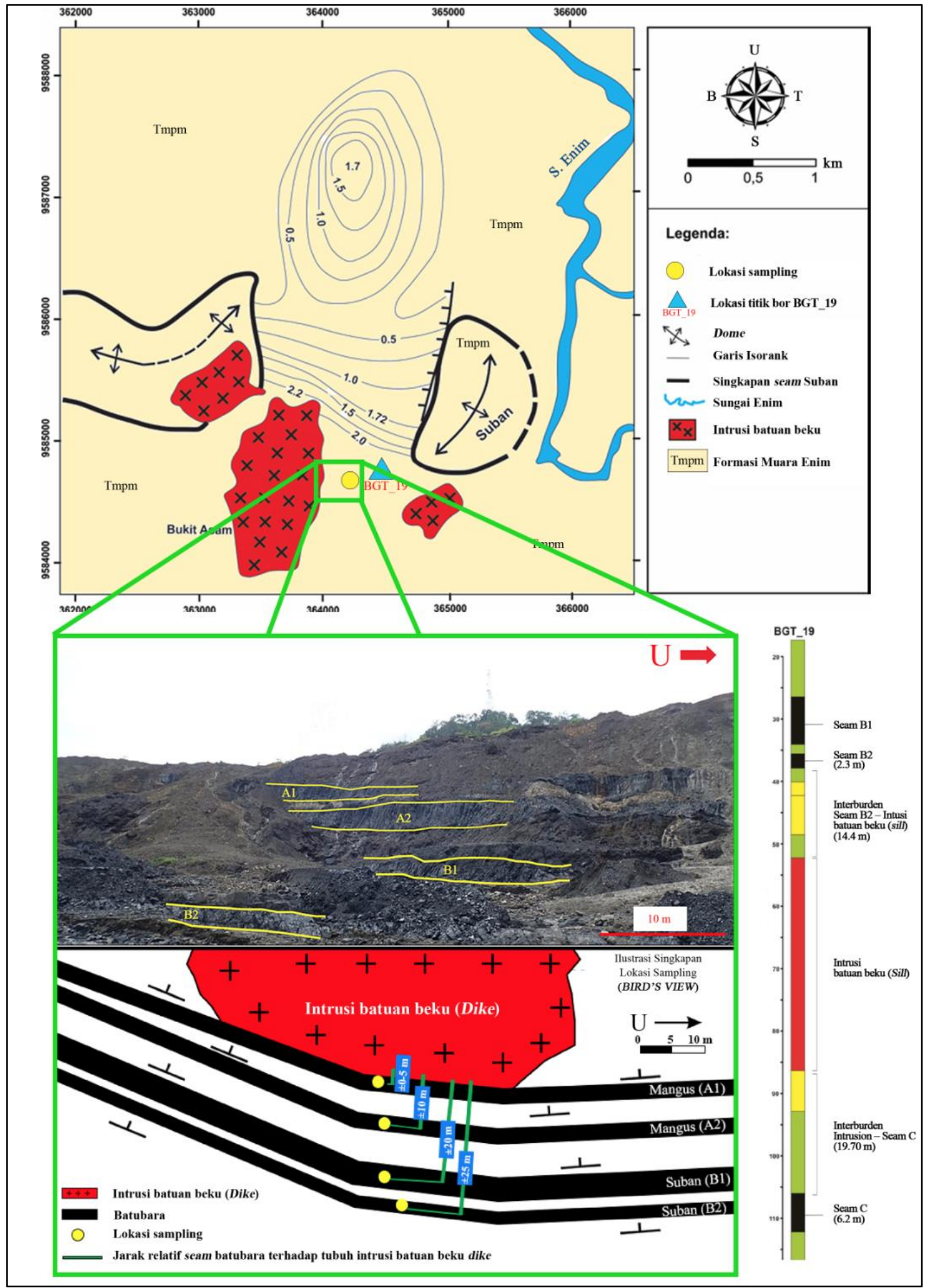

Gambar 3. Peta lokasi penelitian dan ilustrasi singkapan (PT. Bukit AsamTbk., 2012) yang menunjukkan jarak relatif pengambilan sampel dengan tubuh intrusi dike serta data log BGT_19 yang diberikan menunjukkan hadirnya intrusi sill pada kedalaman $14 \mathrm{~m}$ di bawah B2 (PT. Bukit Asam Tbk., 2010) 


\section{HASIL DAN PEMBAHASAN}

\section{HASIL}

\section{Karakteristik Makroskopis}

Berdasarkan hasil observasi secara makroskopis, sampel batubara (A1, A2, B1, dan B2) di lokasi penelitian memiliki litotipe bright banded coal. Batubara A1 yang memiliki jarak terdekat dengan kontak intrusi dicirikan dengaan dijumpainya deformasi berupa struktur kolumnar yang hadir diakibatkan adanya metamorfisme kontak. Bukti adanya intrusi juga terekam pada lapisan interburden berupa batupasir antara seam A1 dan A2 yang mana lapisan yang berkontak langsung dengan terobosan intrusi tersebut mengalami pengerasan tekstur yang merupakan implikasi dari baking effect atau efek panggang yang diakibatkan intrusi (Gambar 4).

\section{Karakteristik Petrografi}

Hasil analisis maseral dan mineral (Gambar 5) menunjukkan bahwa seluruh sampel batubara penyusunnya didominasi oleh vitrinit $(85,8-93,3 \%)$, liptinit lebih sedikit $(2,5-7 \%)$ serta lebih sulit diamati, kemudian diikuti inertinit $(1,8-6 \%)$, dan mineral matter (1,1-2,23\%), sebagian besar berupa mineral lempung, pirit, dan kuarsa (Tabel 1). Pada kenampakan mikroskopis batubara A1 sudah menunjukkan banyaknya pori serta struktur vesikel yang menjadi indikasi devolatilisasi (Gambar 6). Struktur ini sangat jarang dijumpai pada sampel A2, B1, dan B2 yang memiliki jarak yang lebih jauh dari tubuh intrusi dike.

Pada Tabel 1 juga ditampilkan hasil analisis random vitrinite reflectance $\left(R_{v r}\right)$ dari tiap sampel. Nilai yang didapat juga digunakan untuk menentukan peringkat masing-masing sampel batubara. Batubara A1 mencapai $2,01 \%$ mean random reflectance (low volatile bituminous coal), A2 mencapai $1,68 \%$ (medium volatile bituminous coal), B1 mencapai 1,27\% (high volatile bituminous coal), dan B2 memiliki nilai $1,88 \%$ (low volatile bituminous coal).

\section{Analisis Proksimat}

Hasil analisis proksimat tiap sampel (Tabel 1) menunjukkan bahwa ash yield (kadar abu) tiap sampel senilai 2,1-4,2\%, kandungan moisture (kadar lengas) 2,9$4,1 \%$, kandungan volatile matter (kadar zat terbang) $7,8-29,1 \%$, dan fixed carbon (karbon tertambat) $65,5-88,8 \%$.

\section{Identifikasi mineral matter}

Berdasarkan hasil pengamatan petrografi (Tabel 1) diketahui bahwa batubara $A 1$ memiliki kandungan mineral sebesar 2,23\%, A2 memiliki 1,1\%, B1 memiliki 1,5 $\%$ dan $\mathrm{B} 2$ dengan $1,2 \%$.

Analisis XRD (Gambar 7) digunakan untuk mendukung data petrografi serta mengidentifikasi kehadiran mineral yang kurang dapat diamati secara visual menggunakan mikroskop. Berdasarkan identifikasi nilai d serta 2-theta (Gambar 7), mineralogi batubara tiap sampel disarikan pada Tabel 1. Smektit, ilit, dan rektorit merupakan mineral yang teridentifikasi pada A1 dan seiring bertambahnya jarak terhadap intrusi, mineral ilite dan rektorit jarang atau bahkan tidak ditemui. Pada analisis XRD mineral grafit hanya teridentifikasi pada batubara A1 dan B2. Analisis XRD untuk menentukan kehadiran grafit pada batubara mempunyai tingkat akurasi atau tingkat kepercayaan data yang ada tidak terlalu tinggi sehingga diperlukan analisis pendukung lainnya seperti analisis TIC untuk melihat kandungan karbon inorganik dan juga analisis micro-Raman spectroscopy untuk mengetahui derajat pembatubaraan tiap sampel.

Hasil analisis TC, TIC, dan TOC ditampilkan pada Tabel 1. Berdasarkan hasil tersebut diketahui B2 (jarak terjauh terhadap intrusi dike) memiliki kandungan TIC yang tertinggi senilai $6,01 \%$ sedangkan A1 yang memiliki jarak terdekat dengan intrusi memiliki nilai $3,42 \%$. Masing-masing sampel juga diuji dengan analisis micro-Raman spectroscopy. Pada Gambar 8 tampak dua gelombang 
yakni $D$ dan $G$ yang mendekati nilai sekitar 1360 dan $1590 \mathrm{~cm}^{-1}$. Kedua gelombang ini digunakan untuk mengetahui derajat pembatubaraan yang dialami tiap sampel batubara serta digunakan juga untuk dapat mendukung data lain dalam pengidentifikasian potensi kandungan grafit pada batubara lokasi penelitian.
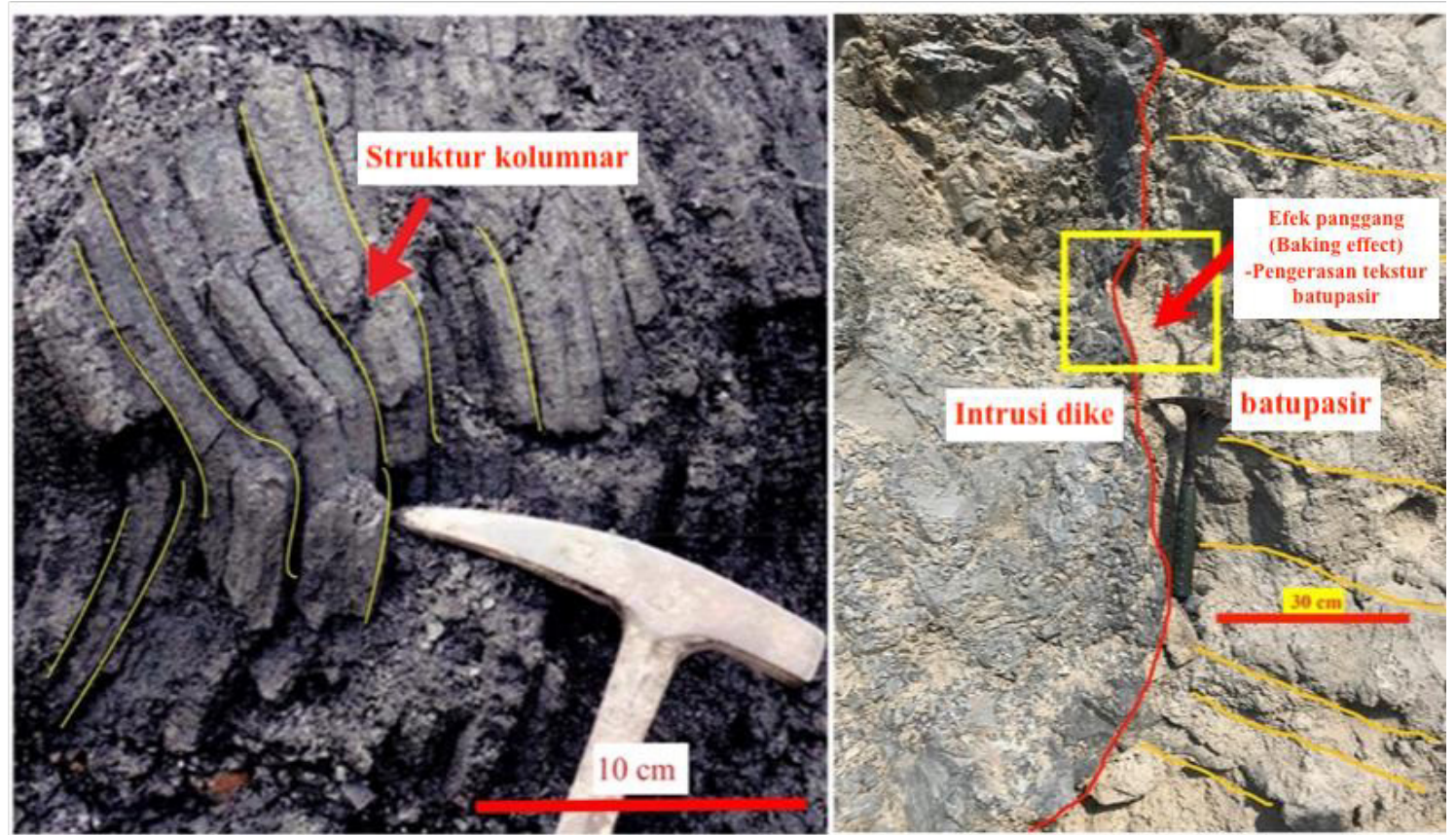

Gambar 4. Bukti adanya metamorfisme kontak pada batubara A1.

Struktur komlumnar (kiri) dan baking effect pada batupasir (kanan)
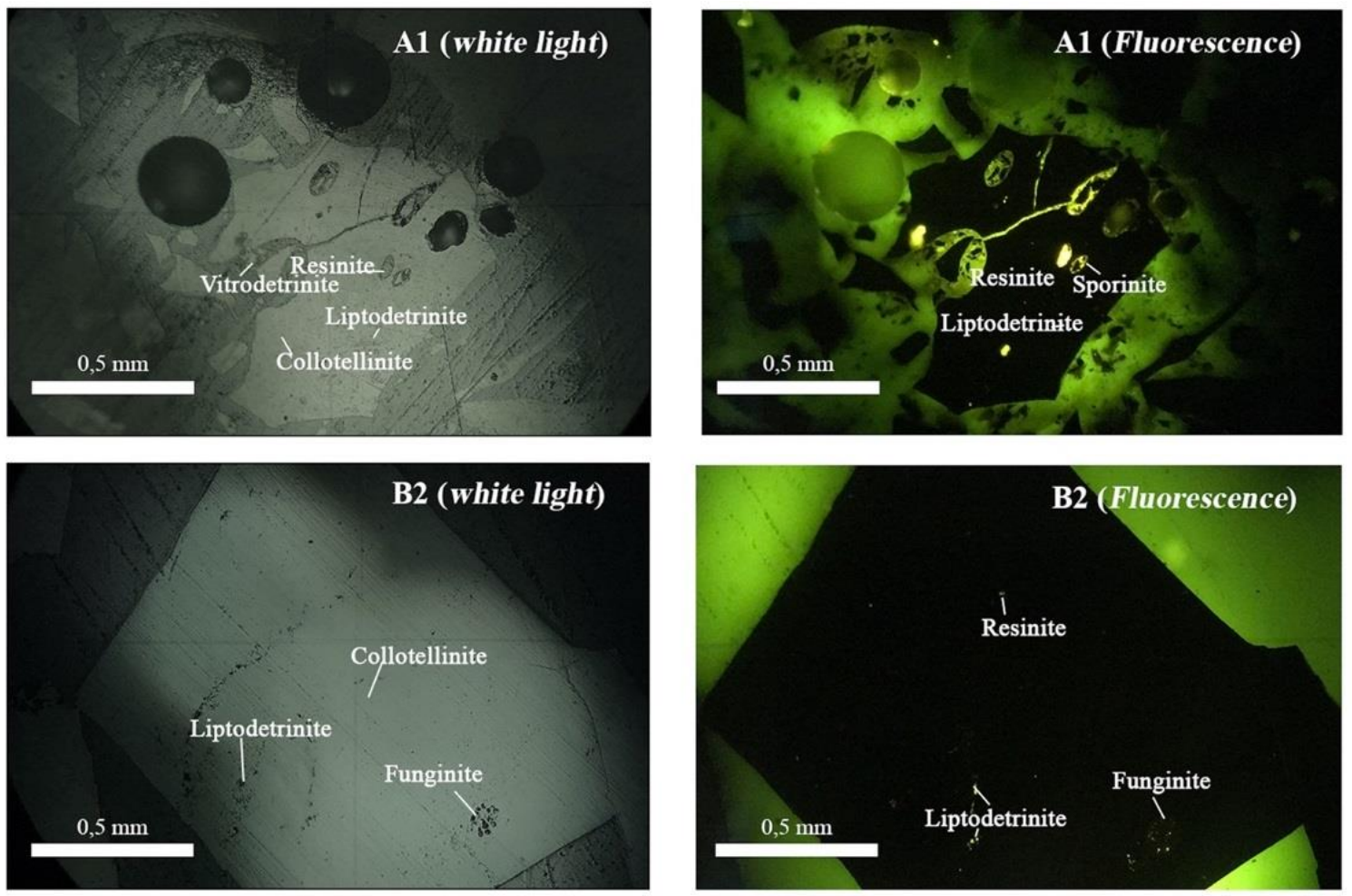

Gambar 5. Contoh kenampakan batubara A1 (atas) dan B2 (bawah) dibawah mikroskop dengan pengamatan white light dan fluorescence 


\section{MAKALAH ILMIAH}



Gambar 6. Struktur Vesikel pada batubara A1.

Struktur ini mengindikasikan adanya devolatilisasi
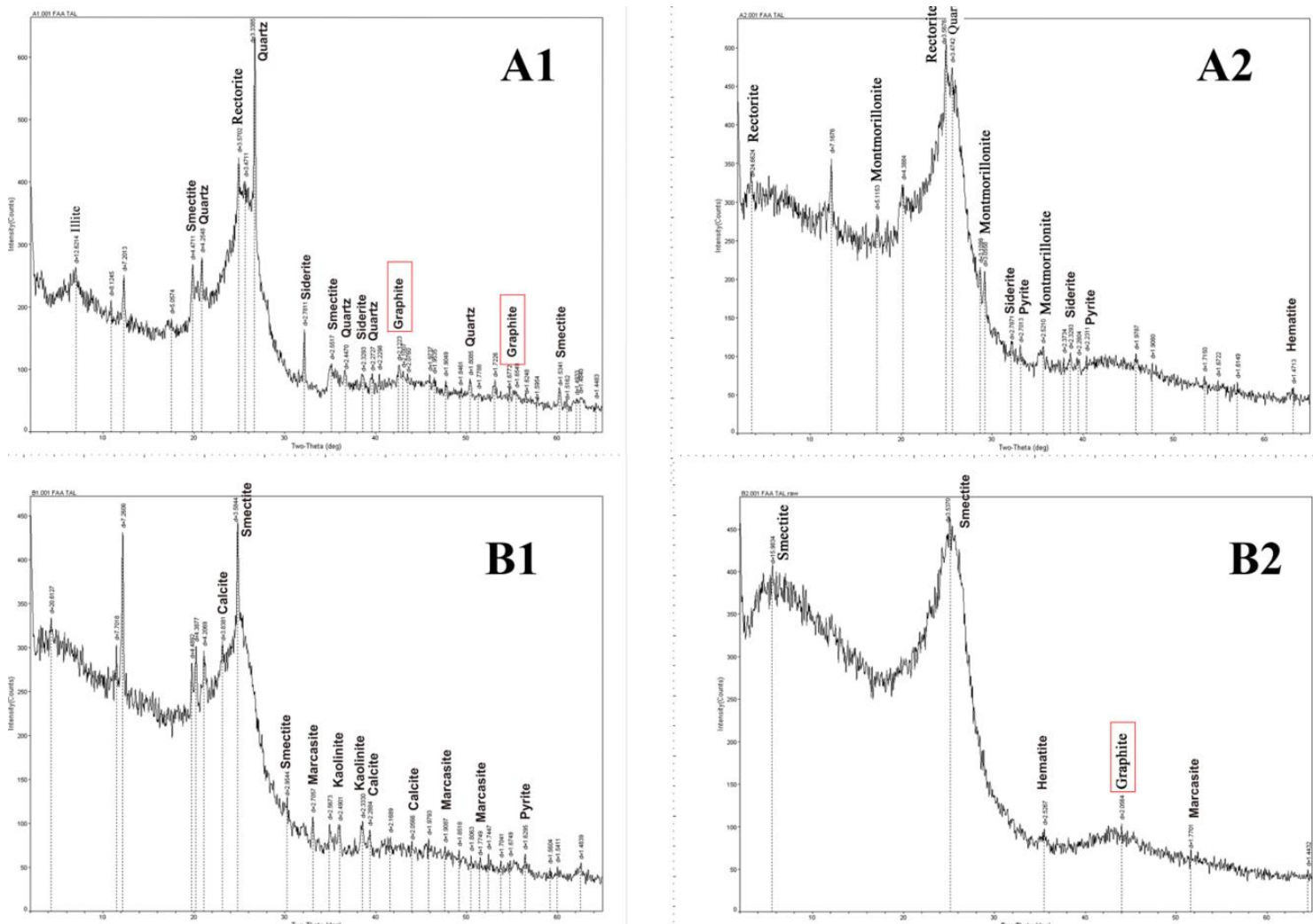

Gambar 7. Hasil analisis XRD tiap sampel.

Grafit hanya teridentifikasi pada batubara A1 dan B2 


\section{MAKALAH ILMIAH}

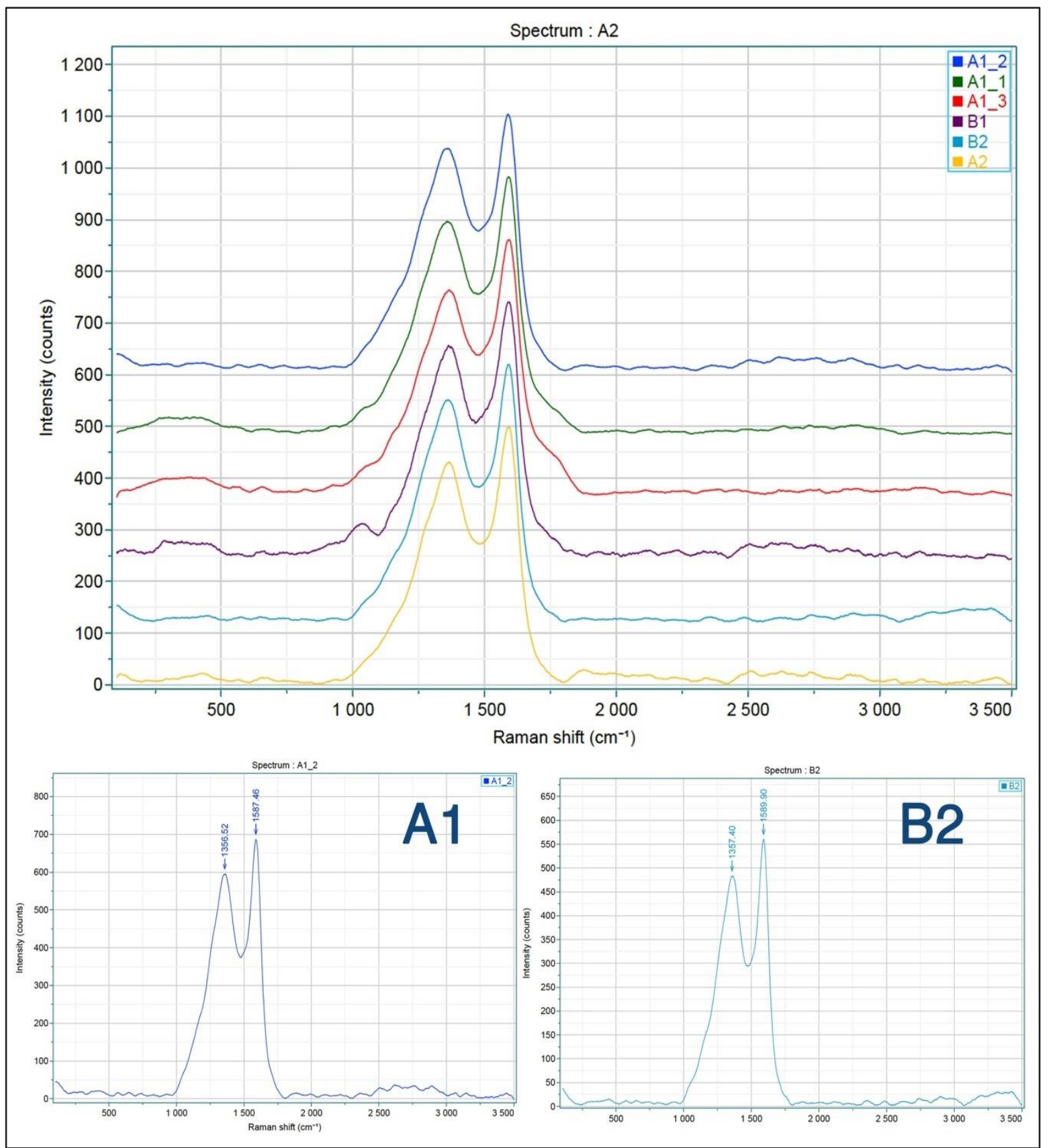

Gambar 8. Perbandingan hasil pengukuran analisis micro-Raman Spectroscopy tiap sampel serta perbandingan khusus pengujian pada sampel yang dijumpai adanya grafit yakni sampel A1 dan B2. 


\section{MAKALAH ILMIAH}

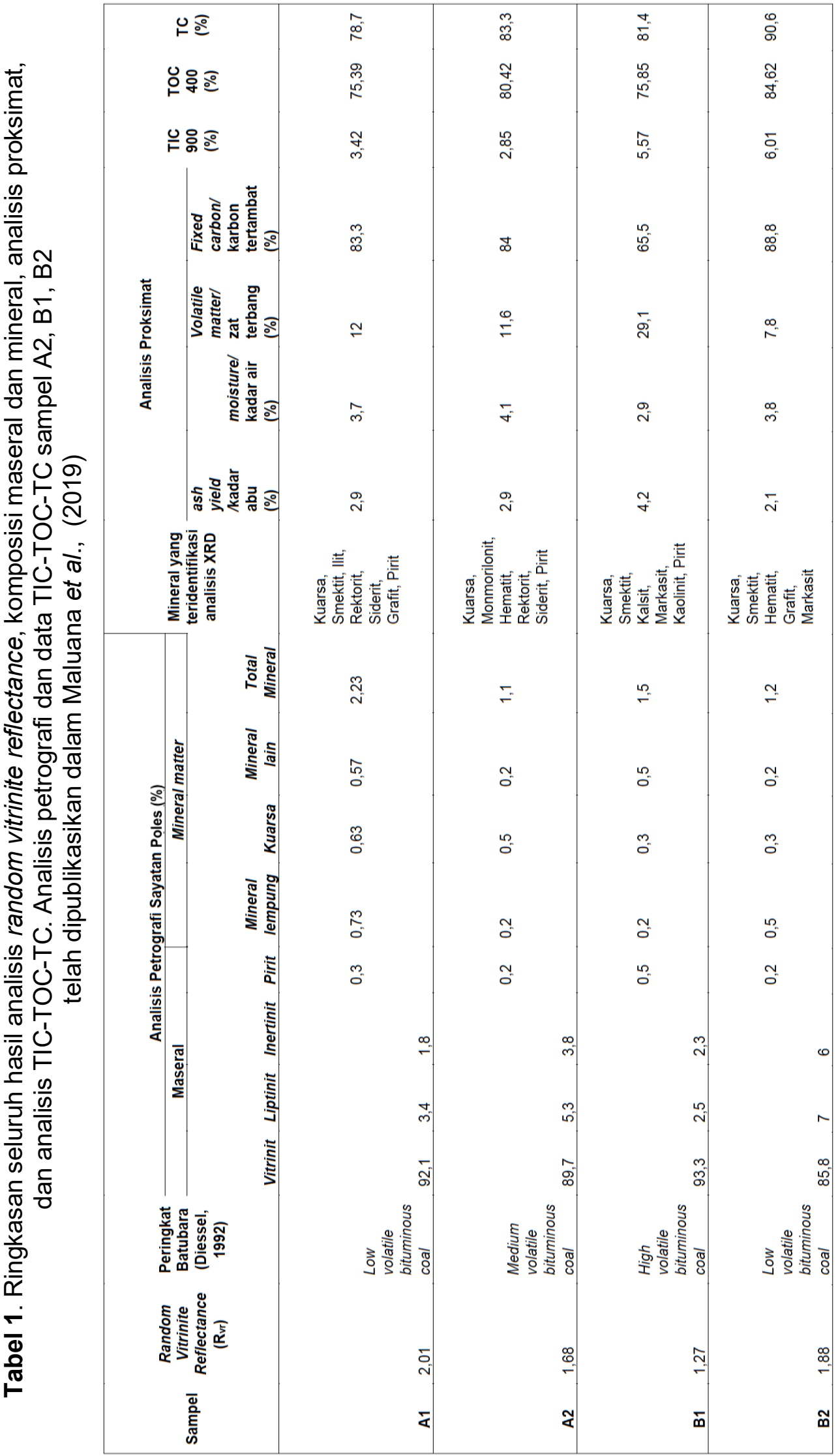




\section{PEMBAHASAN}

\section{KARAKTERISTIK BATUBARA TERPENGARUH INTRUSI}

\section{Kenampakan makroskopis batubara terpengaruh intrusi}

Berdasarkan data yang diperoleh di lapangan diketahui bahwa sampel A1, A2, B1, dan B2 memiliki litotipe bright banded. Kenampakan batubara yang berasal dari seam A1 memiliki kesan lebih kusam yang diakibatkan oleh pemanasan dan kenaikkan peringkat secara cepat yang dikarenakan hadirnya intrusi (O'Neill, 2016). Berkebalikan dengan batubara A1, batubara B2 yang mempunya jarak terjauh dari tubuh intrusi dike memiliki kilap yang paling cerah dibandingkan sampel lainnya karena durasi burial coalification atau pembebanan yang terlama dibanding sampel lainnya. Bukti makroskopis pengaruh intrusi terhadap batubara daerah penilitian adalah ditemukannya struktur kolumnar (Gambar 4) hanya pada batubara A1 yang memiliki jarak terdekat dari tubuh intrusi. Struktur ini muncul akibat hadirnya panas secara tiba-tiba pada seam batubara yang dekat dengan kontak intrusi sehingga terjadi devolatilisasi pada batubara tersebut (Pareek, 1965).

\section{Maseral batubara terpengaruh intrusi}

Berdasarkan kenampakan petrografi maseral tiap sampel menunjukkan adanya perbedaan terutama pada kenampakan kelompok maseral vitrinit masing-masing sampel. Pada sampel batubara seam A1 yang memiliki jarak terdekat terhadap tubuh intrusi memperlihatkan tektstur dari maseral yang cenderung sudah tidak utuh atau terkesan terpecah-pecah serta tampak juga pori atau struktur vesikel dengan jumlah yang signifikan pada sampel A1 (Gambar 6). Struktur tersebut mengindikasikan adanya proses devolatilisasi yang datang secara cepat dan tiba-tiba yang diakibatkan oleh intrusi (Amijaya dan Littke, 2005). Sedangkan pada sampel A2, B1, dan B2 yang berturutturut jaraknya semakin jauh dari tubuh intrusi dike tidak diketemukan adanya struktur vesikel akibat devolatilisasi seperti yang dijumpai pada batubara A1.

\section{Random vitrinite reflectance batubara terpengaruh intrusi}

Data random vitrinite reflectance yang diperoleh pada Tabel 1 menunjukkan bahwa seluruh sampel memiliki rentang nilai rata-rata random vitrinite reflectance sebesar 1,27 - 2,01\% yang berarti seluruh sampel merupakan batubara yang terpengaruh intrusi. Penentuan peringkat batubara pada penelitian ini akan menggunakan nilai vitrinite reflectance. Nilai vitrinite reflectance dapat menunjukkan derajat pembatubaraan yang merupakan proses yang dikontrol oleh temperatur serta durasi pemanasan (Stach et al., 1982). Berdasarkan konsep burial coalification $i$ atau pembebanan massa, maka kenaikan nilai peringkat batubara akan terjadi seiring bertambahnya kedalaman (Thomas, 2002) sehingga seharusnya batubara B2 sebagai seam tertua memiliki peringkat tertinggi dan dilanjutkan oleh batubara $\mathrm{B} 1, \mathrm{~A} 2$, dan $\mathrm{A} 1$ secara berurutan dengan memiliki peringkat lebih rendah. Namun berdasarkan data pengukuran vitrinite reflectance pada Tabel 1 terdapat anomali pada nilai random vitrinite reflectance yang didapat. Batubara A1 yang seharusnya merupakan batubara termuda memiliki nilai reflektansi yang paling tinggi $(2,01 \%)$ dibandingkan batubara seam A2, B1, dan B2. Hal ini mengindikasikan bahwa batubara seam A1 telah terpengaruh oleh intrusi dan juga lokasi pengambilan sampel batubara A1 dengan peringkat low volatile bituminous coal merupakan yang terdekat dengan tubuh intrusi. Pada batubara B2 yang lokasinya terjauh terhadap tubuh intrusi juga berperingkat sama dengan batubara A1 diakibatkan oleh burial coalification atau pembebanan yang terjadi dan juga apabila mengacu kepada Shell Mijnbouw (1978) dan Pujobroto (1997) terdapat intrusi konkordan yang disebut intrusi sill Suban yang berada di bawah seam B2 atau tepatnya berada di antara seam B2 dan C. Sehingga hal tersebut yang menyebabkan pengaruh intrusi terhadap batubara B2 juga intensif. 


\begin{abstract}
Analisis proksimat terpengaruh intrusi

batubara

Berdasarkan Teichmüller \& Teichmüller (1979) penurunan nilai moisture (kadar lengas) dan volatile matter (zat terbang) merupakan indikasi kenaikkan peringkat batubara akan tetapi berdasarkan analisis data proksimat yang telah dilakukan penurunan nilai kandungan moisture (kadar lengas) dan volatile matter (zat terbang) dari seam B2 menuju seam A1 tidak menunjukkan pola kenaikan atau penurunan. Begitu pula peningkatan kandungan fixed carbon (karbon tertambat) yang kurang signifikan. Sedangkan ash yield (kadar abu) yang didapat tidak menunjukkan adanya tren peningkatan. Menurut Rimmer, et al. (2009) kandungan ash yield (kadar abu) memiliki kecenderungan untuk meningkat seiring dekatnya jarak seam batubara terhadap tubuh intrusi akan akan tetapi hal ini tidak selalu terjadi.
\end{abstract}

Sehingga dapat dikatakan bahwa perbedaan signifikan yang terkait dengan derajat pembatubaraan hanya terlihat dari data random vitrinite reflectance (Tabel 1) bahwasannya batubara A1 yang memiliki jarak terdekat dengan tubuh intrusi dike memiliki nilai random vitrinite reflectance yang yang paling tinggi $(2,01 \%)$ dibandingkan dengan batubara $\mathrm{A} 2, \mathrm{~B} 1$, dan B2 yang berarti bahwa derajat pembatubaraan yang dialami batubara A1 merupakan yang tertinggi pada lokasi penelitian.

\footnotetext{
Mineralogi batubara terpengaruh intrusi Mineralogi sampel daerah penelitian didapatkan dari hasil pengamatan petrografi (Tabel 1) yang kemudian didukung dengan analisis XRD (Gambar 7 dan Tabel 1). Pengamatan petrografi (Tabel 1) menunjukkan bahwa kandungan mineral pada sampel yang diteliti nilainya cukup rendah. Sampel batubara terpengaruh intrusi seam A1 memiliki kandungan mineral yang tertinggi dengan nilai $2,23 \%$. Beberapa mineral yang dapat teramati secara visual dalam pengamatan petrografi diantaranya kuarsa, mineral lempung, dan pirit. Berdasarkan
}

kelimpahannya mineral pirit adalah yang paling jarang dijumpai dibandingkan mineral lempung dan kuarsa. Batubara A1 memiliki kandungan mineral lempung tertinggi dengan nilai $0,73 \%$. Kandungan mineral pada sampel penelitian yang rendah dan sulitnya untuk diamati secara visual maka dilakukan analisis XRD untuk membantu mengidentifikasi mineral yang terkandung dalam sampel. Pada batubara seam A1 teridentifikasi kuarsa dengan peak dengan intensitas tertinggi yakni $\sim 3,34 \AA$ dan $\sim 4,25 \AA$. Mineral lempung yang teridentifikasi berupa ilit pada peak $\sim 4,5 \AA$ dan $\sim 12,9 \AA$, smetit pada peak $\sim 4,4$ $\AA$ serta hadirnya rektorit yang merupakan mineral lempung yang terdiri atas mika dioktahedral dan smektit yang dicirikan pada peak 3,57 A. Teridentifikasi pula kehadiran mineral grafit yang menunjukkan peak $\sim 2,12 \AA$ dan $\sim 1,67 \AA$. Pada batubara A2 mineral lempung yang teridentifikasi berupa rektorit dan montmorillonit pada peak $\sim 5,1 \AA$ dan $\sim 3,05 \AA$. Pada batubara A2, B1, dan B2 juga teridentifikasi pula mineral karbonat seperti siderit dan kalsit serta mineral sulfida seperti pirit dan markasit. Pada batubara B2 teridentifikasi hadirnya mineral grafit dengan intensitas yang lemah pada peak $2,05 \AA$. Berdasarkan data yang diperoleh (Gambar 7 dan Tabel 1) dapat diketahui bahwa terdapat perubahan mineralogi seiring dengan bertambahnya peringkat batubara. Menurut Susilawati dan Ward (2006) yang melakukan penelitian di lokasi penelitian yang sama menyatakan bahwa batubara yang mengalami kenaikan peringkat akibat terpengaruh intrusi akan mengandung interstratifikasi ilit/smektit, rektorit, dan paragonit di beberapa kasus dengan proporsi yang signifikan serta adanya pengurangan kandungan kaolinit. Apabila dilihat dari hasil XRD sampel penilitian tampak bahwa sampel A1 yang terdekat dengan tubuh intrusi teridentifikasi mineral seperti smektit, ilit, dan rektorit serta tidak teridentifikasinya kehadiran kaolinit. Sebaliknya, pada batubara B1 yang posisinya lebih jauh dari tubuh intrusi dibanding dengan batubara $\mathrm{A} 1$, peak mineral kaolinit masih dapat teridentifikasi karena proses ilitisasi pada batubara 
tersebut masih belum intens sehingga tidak ditemukan ilit ataupun rektorit. Proses perubahan mineralogi ini diakibatkan dari proses pemanasan oleh tubuh intrusi yang memungkinkan memindahkan kandungan moisture (kadar lengas), elemen inorganik pada batubara peringkat rendah atau fluida panas menuju lapisan pembawa batubara sehingga komponen mineral pada batubara tersebut akan terubah (Susilawati dan Ward, 2006).

\section{POTENSI BATUBARA TERPENGARUH INTRUSI SEBAGAI MATERIAL PEMBUATAN GRAFIT SINTETIS}

Proses pembatubaraan yang dialami oleh batubara selama terendapkan merupakan gabungan proses biologi, kimia, dan fisika yang dipengaruhi oleh pembebanan sedimen, temperatur, tekanan dan waktu (Stach, 1982). Seiring dengan peningkatan derajat pembatubaraan yang dialami batubara yang juga disertai dengan kenaikkan peringkat batubara maka pada suatu kondisi akan memasuki tahap grafitisasi (Levine,1993). Pada lokasi penelitian ditemui faktor lain yang yang menyebabkan meningkatnya derajat pembatubaraan selain burial coalification atau pembebanan yakni pengaruh intrusi dike yang hadir sehingga panas yang dihasilkan intrusi tersebut berkontribusi dalam peningkatan derajat pembatubaraan batubara di lokasi penelitian. Pengamatan dan analisis yang telah dilakukan pada seluruh sampel diketahui bahwa batubara A1 yang memiliki jarak terdekat dengan tubuh intrusi mengalami perubahan karakteristik akibat dari panas intrusi yang lebih intens dibandingkan dengan batubara lainnya.

Secara makroskopis, pada batubara A1 terdapat kenampakan struktur kolumnar (Gambar 4) yang disebabkan oleh proses devolatilisasi akibat panas intrusi (Pareek, 1965). Sruktur ini tidak dijumpai pada sampel A2, B1, dan B2 yang jaraknya berturut-turut semakin jauh dari tubuh intrusi. Hal ini merupakan indikasi awal pada penelitian bahwa batubara A1 telah mengalami kenaikkan derajat pembatubaraan tertinggi dibanding batubara lainnya yang dipengaruh dari intrusi.

Melalui pengamatan mikroskopis tampak batubara A1 menunjukkan kenampakan struktur vesikel yang kerap ditemui (Gambar 6) serta kenampakan bentuk maseral yang terpecah-pecah sedangkan pada batubara A2, B1, B2 kenampakan struktur vesikel jarang atau tidak dijumpai serta memiliki kenampakan bentuk maseral yang utuh dibandingkan batubara $\mathrm{A} 1$. Hal ini merupakan bukti mikroskopis bahwa batubara A1 telah mengalami kenaikkan derajat pembatubaraan tertinggi dibanding batubara lainnya.

Berdasarkan pengukuran vitrinite reflectance (Tabel 1) diketahui bahwa batubara A1 memiliki nilai rata-rata vitrinite reflectance tertinggi yakni sebesar 2,01\% kemudian beturut-turut diikuti dengan nilai yang lebih kecil oleh batubara A2, B1, dan B2. Adanya sedikit kenaikkan nilai vitrinite reflectance pada batubara B2 (\%Ro $=1,88 \%)$ diperkirakan berasal dari keberadaan intrusi sill yang berada di bawah seam B2. Berdasarkan hal tersebut diketahui bahwa peringkat batubara tertinggi pada penelitian ini dimiliki oleh batubara A1 dan B2 yang merupakan low volatile bituminous coal. Secara keseluruhan, terbukti bahwa batubara A1 memiliki derajat pembatubaraan tertinggi yang diindikasikan nilai vitrinite reflectance tertinggi.

Kandungan mineralogi batubara A1 di daerah penelitian diketahui memiliki rerata kandungan mineral tertinggi (2,23\%) dibandingkan sampel batubara lainnya (Tabel 1) dengan ditemui banyak asosiasi mineral penciri batubara berperingkat tinggi seperti ilit, smektit, dan rektorit yang dapat meningkatkan derajat kristalinitas dalam proses pembatubaraan (Susilawati \& Ward, 2006; Rodrigues et al.,2012).

Berdasarkan data yang diperoleh hadirnya mineral grafit pada sampel penelitian hanya dapat teridentifikasi melalui data XRD (Gambar 7 dan Tabel 1). Peak mineral 
grafit dijumpai pada sampel batubara A1 dan B2. Penentuan kehadiran grafit yang hanya didasari oleh analisis XRD memiliki tingkat kepercayaan yang kurang tinggi sehingga perlu dielaborasikan dengan data analisis lainnya untuk mengetahui potensi sampel batubara yang memiliki derajat pembatubaraan tertinggi untuk dapat dijadikan material dalam pembuatan grafit sintetis. Apabila dilihat melalui data TIC (Tabel 1) diketahui bahwa B2 memiliki nilai yang lebih tinggi yakni sebesar $6,01 \%$ sedangkan A1 memiliki rerata nilai 3,42\% akan tetapi kandungan karbon inorganik dari masing-masing sampel belum sepenuhnya merepresentasikan kandungan grafit secara keseluruhan dapat juga ditemukan kandungan karbonat serta $\mathrm{CO}_{2}$ terlarut yang turut serta terhitung. Berdasarkan nilai kandungan ash yield (kadar abu) dari analisis proksimat serta nilai kandungan mineral matter dari pengamatan petrografi diketahui bahwa batubara A1 memiliki nilai rerata yang lebih tinggi dibandingkan dengan nilai B2 sehingga kehadiran mineral grafit berada pada batubara A1 juga menunjukkan bahwa batubara A1 juga memiliki derajat pembatubaraan yang lebih tinggi. Kedua batubara tersebut memiliki peringkat yang sama yakni low volatile bituminous coal, akan tetapi nilai vitrinite reflectance keduanya berbeda. Sampel batubara A1 memiliki nilai rerata vitrinite reflectance senilai 2,01\% sedangkan batubara B2 memiliki nilai yang lebih rendah yakni $1,88 \%$ yang berarti batubara seam $A 1$ memiliki derajat pembatubaraan yang lebih tinggi. Selain itu, berdasarkan data microRaman Spectroscopy juga terlihat bahwasannya intensitas gelombang $D$ dan $G$ yang tertinggi dimiliki oleh batubara A1 (dilakukan tiga kali pengujian untuk sampel A1) dibandingkan dengan batubara lainnya sehingga dapat diartikan bahwa batubara A1 telah mengalami derajat pembatubaraan yang lebih tinggi. Kurva gelombang $D$ dan $G$ pada seam $A 1$ berada pada nilai sekitar 1360 dan $1590 \mathrm{~cm}^{-1}$ dan nilai ini mendekati kurva grafit.

Berdasarkan Levine (1993) salah satu karakteristik batubara yang berubah akibat metaforfisme yang dipengaruhi intrusi adalah meningkatnya peringkat atau derajat pembatubaraan yang dialami oleh batubara tersebut serta kenaikkan derajat pembatubaraan juga erat kaitannya dengan meningkatnya pula derajat kristalinitas dari material karbon penyusun batubara tersebut hingga mencapai tahap terbentuknya grafit atau grafitisasi. Proses pembatubaraan hingga grafitisasi dikontrol oleh temperatur, waktu, material penyusun asal, aktifitas fluida di sekitar batuan, tekanan serta tegangan dan regangan akibat deformasi yang terjadi pada batuan tersebut (Large et al., 1994). Akan tetapi, parameter pengontrol pembatubaraan termasuk juga grafitisasi tersebut belum dapat dikaji secara kuantitatif serta komprehensif (Beyssac et al., 2002).

Berdasarkan Nakamura dan Akai (2013) dan Aoya et al. (2010) diketahui bahwa perubahan material organik menjadi grafit akibat metamorfisme yang terjadi dan diamati melalui perubahan struktur serta ukuran kristal dapat berlangsung dimulai dari terbentuknya butiran grafit amorf (amorphous graphite) yang terbentuk mulai suhu sekitar $330^{\circ} \mathrm{C}$ hingga $370^{\circ} \mathrm{C}$ lalu semakin meningkatnya temperatur disertai dengan perubahan struktur menjadi semakin baik hingga memasuki temperatur di atas $600^{\circ} \mathrm{C}$ material karbon yang ada dapat terubah menjadi grafit dengan bentukan heksagonal. Hal serupa juga disampaikan Buseck dan Beyssac (2014) bahwa material karbon yang sudah terubah menjadi grafit amorf akan mengalami tranformasi menjadi grafit dengan struktur heksagonal atau dapat dikatakan bahwa seiring peningkatan metamorfisme yang diindikasikan dari peningkatan temperatur dapat meningkatkan derajat kristalinitas material karbon yang terkandung pada batubara hingga dapat terbentuknya grafit.

Hal tersebut dapat menjadi dasar bahwa batubara A1 di lokasi penelitian diperkirakan memiliki potensi terbesar untuk dijadikan sebagai material pembentukan grafit sintetis. Hal ini dikarenakan batubara A1 memiliki jarak terdekat terhadap kontak intrusi yang 
diperkirakan bertemperatur sekitar 700$750^{\circ} \mathrm{C}$ (Amijaya dan Littke, 2005) sehingga batubara A1 memiliki derajat pembatubaraan yang tertinggi dibandingkan dengan seam batubara terpengaruh intrusi lainnya.

\section{KESIMPULAN}

Berdasarkan seluruh analisis yang dilakukan diketahui bahwa batubara terpengaruh intrusi di lokasi penelitian berlitotipe bright banded dengan peringkat high volatile bituminous coal - low volatile bituminous coal (\%Ro $=1,27 \%-2,01 \%$ ) dengan kandungan kelompok maseral vitrinite yang dominan. kelompok maseral vitrinite yang dominan. Batubara terpengaruh intrusi di daerah penelitian kurang menunjukkan adanya penurunan nilai moisture (kadar lengas) dan volatile matter (zat terbang) serta fixed carbon (karbon tertambat) yang meningkat secara signifikan. Nilai ash yield (kadar abu) pada batubara tidak menunjukkan adanya peningkatan seiring berkurangnya jarak terhadap tubuh intrusi.

Potensi tertinggi batubara terpengaruh intrusi di lokasi penelitian yang dapat dijadikan sebagai material pembuatan grafit sintetis akan dijumpai pada batubara terpengaruh intrusi pada seam A1 yang memiliki jarak terdekat terhadap tubuh intrusi yakni sekitar 0-5 m dari tubuh intrusi dengan derajat pembatubaraan tertinggi mencapai peringkat low volatile bituminous coal $(\%$ Ro $=2,01 \%)$, dan nilai intensitas gelombang $G$ dan $D$ yang tertinggi mendekati kurva gelombang grafit, serta kandungan ash yield (kadar abu) 2,9 wt.\%, adb; total mineral 2,23 vol. $\%$ dengan asosiasi mineral lempung yang dijumpai berupa ilit, smektit, dan rektorit yang merupakan mineral penciri batubara berperingkat tinggi yang dapat meningkatkan derajat kristalinitas dalam proses pembatubaraan.
Sehingga dari keseluruhan sampel batubara diketahui bahwa batubara terpengaruh intrusi yang paling berpotensi untuk dijadikan sebagai material pembuatan grafit secara berurutan adalah A1, B2, A2, dan B1. Batubara A1 dengan derajat pembatubaraan tertinggi paling berpotensi untuk dijadikan sebagai material pembuatan grafit sintetis pada proses selanjutnya dibandingkan batubara $\mathrm{B} 2, \mathrm{~A} 2$, dan $B 1$ yang berturut-turut memiliki derajat pembatubaraan yang lebih rendah dari batubara A1.

\section{DAFTAR PUSTAKA}

Amijaya, H., dan Littke, R., 2005. Paleoenvironmental, paleoecological and thermal metamorphism implication on the organic petrography and organic geochemistry of Tertiary Tanjung Enim coal, South Sumatra Basin, Indonesia, [Dissertation]: Germany, RWTH Aachen, p.157.

Aoya, M., Kouketsu, Y., Endo, S., Shimizu, H., Mizukami, T., Nakamura, D., dan Wallis, S., 2010. Extending the applicability of the Raman carbonaceous-material

geothermometer using data from contact metamorphic rocks, Journal of Metamorphic Geology 28, p. 895914.

ASTM D2799-05a, 2005. Test Method for Microscopical Determination of the Maceral Composition of Coal.

ASTM D3172-13, 2013. Standard Practice for Proximate Analysis of Coal and Coke, Annual Book of Standards, vol 05.

ASTM D3173-03, 2005. Test Method for Moisture in the Analysis Sample of Coal and Coke: Gaseous Fuels; Coal and Coke. vol. 05.

ASTM D3174-04, 2005. Test Method for Ash in the Analysis Sample of Coal and Coke: Gaseous Fuels; Coal and Coke. vol. 05. 
ASTM D3175-02, 2005. Test Method for Volatile Matter in the Analysis Sample of Coal and Coke: Gaseous Fuels; Coal and Coke. vol. 05.

Beyssac, O., Chopin, C., Rouzaud, J.N. dan Goffe, B., 2002 Raman spectra of carbonaceous material in metasediments: a new geothermometer, Journal of Metamorphic Geology 20, p. 859871. OK

Buseck, P., dan Beyssac, O., 2014. From Organic Matter to Graphite: Graphitization, Elements 10, p. 421426.

Chen, P.Y., 1997. Table of Key Lines in XRay Powder Diffraction Patterns of Minerals in Clays and Associated Rocks, Department of Natural Resources Geological Survey Occasional Paper 21, p. 1-38.

de Coster, G.L., 1974. The Geology of Central and South Sumatra Basins. In: Proceedings 3rd Annual Convention Indonesian Petroleum Association, p. 77-110.

Chung, D.D.L., 2002. Review Graphite, Journal of Materials Science 37, p. 1475-1489.

Daly, M.C., Hooper, B.G.D., Smith, D.G., 1987. Tertiary plate tectonics and basin evolution in Indonesia. Proceedings of the 6th Regional Congress on Geology, Mineral and Hydrocarbon Resources of Southeast Asia (GEOSEA VI), Jakarta, p.1-28.

Darman, H., Sidi, F.H., 2000. An outline of the geology of Indonesia. Indonesian Association of Geologists, Jakarta. $254 \mathrm{p}$.

Daulay, B., Ningrum, N.S., Cook, A.C., 2000. Coalification of Indonesian coal, Proceedings of Southeast Coal Geology Conference: . Bandung, Directorate General of Geology and Mineral Resources of Indonesia, $p$. 85-92.

Diessel, C.F.K., 1992. Coal-bearing Depositional Systems. Springer Verlag, Berlin. p. 721.
Franklin, R.E., 1951. Crystallite growth in graphitizing and non-graphitizing carbons, Proceeding The Royal Society London A 209, p. 196-218.

Girard, I., and Klassen, R.A., 2001. A comparison of seven methods or analysis of carbon in soils, Geological Survey of Canada, Current Research 2001-E11, p. 9.

International Committee for Coal and Organic Petrology (ICCP), 1998. The new vitrinite classification (ICCP System 1994), Fuel, vol.77, p. 349358.

International Committee for Coal and Organic Petrology (ICCP), 2001. The new inertinite classification (ICCP System 1994), Fuel, vol. 80, halaman 459-471.

ISO7404-5,2009. Methods for the petrographic analysis of coals - Part 5: Method of determining microscopically the reflectance of vitrinite. Geneva, Switzerland. $14 \mathrm{pp}$.

Large, D.J., Christy, A.G., dan Fallick, A.E. 1994. Poorly crystalline carbonaceous matter in high grade metasediments: implications for graphitisation and metamorphic fluid compositions. Contributions to Mineralogy and Petrology: Berlin, Springer Verlag p. 108-116.

Levine, J.R., 1993. Coalification: The Evolution of Coal as Source Rock and Reservoir Rock for Oil and Gas: Alabama, University of Alabama, p. 39-77.

Lyons, P.c. and Chase, H.B., Jr., 1981. Rank of coal beds of the Narragansett Basin, Massachusetts and Rhode Island: International Journal of Coal Geology, v. 1, p. 155-168.

Maulana, A., Patria, A.A., dan Anggara, F., 2019. Pengaruh Intrusi Terhadap Kandungan Grafit di Batubara Tambang Air Laya Wilayah Pertambangan PTBA Tanjung Enim, Sumatra Selatan, Proceeding Seminar Nasional Kebumian ke-12: Yogyakarta, Teknik Geologi Universitas Gadjah Mada, p. 47-55. 
Nakamura, Y., dan Akai, J., 2013. Microstructural evolution of carbonaceous material during graphitization in the Gyoja-yama contact aureole: HRTEM, XRD and Raman spectroscopic study, Journal of Mineralogical and Petrological Sciences 108(3), p.131-143.

Oberlin, A., Terriere, G., 1975. Graphitization studies of anthracites by high resolution electron microscopy, Carbon 13, p. 367-376.

Olson, D.W., 2015. Graphite (Natural): U.S. Department of the Interior, U.S. Geological Survey, Mineral Commodity Summaries, January 2015, p. 68-69.

O'Neill, T., 2016. An investigation of the self-heating properties of heataffected coal, [published thesis]: Brisbane, School of Mechanical and Mining Engineering, The University of Queensland, p. 56.

Pareek, H.S., 1965. Petrological Characteristic of Barakar Coal Seams, Metamorphosed by Lamprophyre Sill in The Jharia Coalfield, Bihar, Geological Survey of India, p. 261-270.

Pickel, W., Kus, J. Flores, D., Kalaitzidis, S., Christanis, K., Cardott, B.J., MiszKennan, M., Rodrigues, S., Hentschel, A., Hamor-Vido, M., Crosdale, P., dan Wagner, N., ICCP. 2017. Classification of liptinite - ICCP System 1994, International Journal of Coal Geology 169, p. 40-61.

PT. Bukit Asam (Persero) Tbk., 2010. Internal Report on Geophysical Logging. [unpublished]

PT. Bukit Asam (Persero) Tbk., 2012. Internal Report on Intrusion Mapping. [unpublished]

Pujobroto, A., dan Hutton, A.C., 2000. Influence of andesitic intrusions on Bukit Asam coal, South Sumatra Basin Indonesia, Proceeding Southeast Coal Geology Conference: Bandung, Directorate General of Geology and Mineral Resources of Indonesia, p. 81-84.
Pujobroto, A., 1997. Organic petrology and geochemistry of Bukit Asam coal, South Sumatra, Indonesia, [Unpublished Ph.D. thesis]: Australia, University of Wollongong, p. 397.

Rimmer, S.M., Yoksoulian, L.E., Hower, J.C., 2009. Anatomy of an intruded coal, I: Effect of contact metamorphism on whole-coal geochemisry, Springfield (No.5) (Pennsylvanian) coal, Illinois Basin, International Journal Coal Geology 79, p. 74-82.

Rodrigues, S., Marques, M., Edward, C.R., Suárez-Ruiz, I., Flores, D., 2012 Mineral transformations during high temperature treatment of antrachite, International Journal Coal Geology 94, p. 191-200.

Shell Mijnbouw N.V., 1978. Geological study of the Bukit Asam coal mines: Jakarta, p. 18.

Stach, E., Mackowsy, M., Teichmuller, M., 1982. Coal Petrology, 3rd: Berlin, Gebruder Borntaeger.

Susilawati, R., dan Ward, C.R., 2006. Metamorphism of mineral matter in coal from the Bukit Asam deposit, south Sumatra, Indonesia, International Journal of Coal Geology 68, p. 171-195.

Simandl, G.J., Paradis, S., and Akam, C., 2015. Graphite deposit types, their origin, and economic significance, dalam Prosiding, Symposium on Strategic and Critical Materials, November 2015: Victoria, British Columbia, British Columbia Ministry of Energy and Mines, British Columbia Geological Survey Paper 2015-3, p. 163-171.

Teichmüller, M., Teichmüller, R., 1979. Diagenesis of coal (coalification). In Larsen, G., Chilingar, G.V. (Eds), Diagenesis in Sediments and Sedimentary Rocks: Elsevier, Amsterdam, p. 207-246.

Thomas, L., 2002. Coal Geology: New Jersey, John Wiley \& Sons, Inc., p. 1173.

\begin{tabular}{|ll|}
\hline Diterima & $:$ 2 Oktober 2020 \\
Direvisi & $:$ 14 Oktober 2020 \\
Disetujui & $:$ 30 November 2020 \\
\hline
\end{tabular}

